\title{
41-Pandemi döneminde yapılan uzaktan eğitim çalışmalarıyla ilgili İngilizce öğretmenlerinin görüşleri (bir odak grup tartışması)
}

\section{Seçil TÜMEN AKYILDIZ1}

\begin{abstract}
APA: Tümen Akyıldız, S. (2020). Pandemi döneminde yapılan uzaktan eğitim çalışmalarıyla ilgili İngilizce öğretmenlerinin görüşleri (bir odak grup tartışması). RumeliDE Dil ve Edebiyat Araştırmaları Dergisi, (21), 679-696. DOI: 10.29000/rumelide.835811.
\end{abstract}

$\ddot{O} \mathbf{z}$

Covid-19 küresel salgını eğitim de dâhil olmak üzere yaşamın her alanını etkilemiştir. Bu bağlamda okullar virüsün daha hızlı yayılmasını önlemek için kapatılmış ve uzaktan eğitim sistemine geçiş yapılmıştır. Acil durum çözümlerinde ilk etapta uygulama sorunları yaşanması kaçınılmazdır. Uzaktan eğitim döneminde yabancı dil öğretiminde de uygulama kaynaklı bazı sorunlar tespit edilmiştir. Bu süreçte öğretmenlerin sorumluluğu oldukça fazladır. Bu noktadan hareketle mevcut araştırma pandemi sürecinde İngilizce öğretmenlerinin uzaktan eğitim uygulamalarını, süreçteki problemlerini ve de gelecek uygulamaları için çözüm önerilerini ortaya koymayı amaçlamıştır. Nitel bir araştırma olarak tasarlanan araştırma odak grup tartışması tekniğiyle yürütülmüştür. Araştırmanın katılımcıları pandemi süresince Elazığ ilinde ortaokul düzeyinde çalışan altı İngilizce öğretmenidir. Araştırmanın bulguları pandemi sürecinde yabancı dil öğretiminde öğrenci, öğretmen, teknoloji ve veli kaynaklı birtakım problemler yaşandığını göstermektedir. Katılımcıların gelecek uygulamaları iyileştirecek ve onlara yol gösterecek nitelikte olan önerilerinden bazıları şu şekildedir: Öğretmenler uzaktan eğitim ve teknoloji kullanımı bazında eğitimlerle desteklenmeli; iletişimsel yaklaşım ve etkileşim içeren yabancı dil öğretim yöntemleri uzaktan eğitime uyarlanmalı ve ders saatleri artırılmalı; öğrencilere teknolojiyi öğrenme için kullanmaları doğrultusunda yol gösterilmeli; öğrencilere motivasyon desteği sağlanmalı; öğrencilerin bireysel öğrenme yetenekleri desteklenmeli; veliler süreçle ilgili bilinçlendirilmeli ve de sosyal eşitliği sağlamak için ihtiyacı olan öğretmen ve öğrencilere teknolojik destek sağlanmalıdır.

Anahtar kelimeler: Covid-19 küresel salgını, uzaktan eğitim, yabancı dil öğretimi

\section{EFL teachers' views on the pandemic distance education (a focus group discussion)}

\begin{abstract}
The Covid-19 is a deadly pandemic that has affected every aspect of life including education. The schools have been closed to prevent the spread of the virus, and they have converted their system into distance education. As a part of emergency solutions, it is inevitable to have implementation problems at the first stage. During the distance education period, some practical problems have been identified in foreign language teaching as well. The responsibility of teachers in this pandemic process is far too much. Thus the current research aimed to reveal the distance education practices of English as foreign language (EFL) teachers; the problems they met during the process and their suggestions for future implementations. The study, designed as qualitative research, was carried out by the focus group discussion technique. The participants of the study were six EFL teachers who
\end{abstract}

Dr. Öğr. Üyesi, Fırat Üniversitesi, İnsani ve Sosyal Bilimler Fakültesi, Batı Dilleri ve Edebiyatları Bölümü, İngiliz Dili ve Edebiyatı ABD (Elazı̆̆, Türkiye), stakyildiz@firat.edu.tr, ORCID ID: oooo-0oo13-4116-7344 [Araştırma makalesi, Makale kayıt tarihi: 09.11.2020-kabul tarihi: 20.11.2020; DOI: 10.2900o/rumelide.835811]

Adres
Address

Istanbul Medeniyet University, Faculty of Education Sciences,

Turkish and Social Scinces Education, Turkish Language Teaching

Education, Cevizli Campus, Kartal-İstanbul /TURKEY

e-mail: editor@rumelide.com 
worked at the secondary school level in Elazig during the pandemic period. The findings have revealed that some problems in the EFL teaching process were caused by students, teachers, technology and parents. Some of the suggestions of the participants that will guide and improve the future practices are as follows: Teachers should be trained on distance education and technology use; EFL teaching methods including an adaptation of communicative approach and interaction to distance education; course hours should be increased; students should be guided in using technology for their learning; students should be provided with motivational support; their individual learning abilities should be supported; parental awareness about distance education should be raised to ensure social equality, and technical support should be offered to teachers and students who need it.

Keywords: Covid-19 pandemic, distance education, EFL teaching

\section{Giriş}

Yaşadığımız Covid-19 küresel salgını dünya çapında birçok alanı aksatmakta ve neticelerini kestirmek her geçen gün zorlaşmaktadır. Evde kalmanın güvenli olduğu farklı sloganlarla dünyada kabul görmektedir (UNESCO, 2020). Bu durumun eğitimi de ciddi bir biçimde etkilediği ortadadır. Nitekim, pek çok dünya ülkesinde olduğu gibi Türkiye'de de her kademede okullar uzaktan eğitim sistemine dönüştürülmüştür ve de süregelen dönemde de bu sistemin devam edebileceği öngörüler arasında yer almaktadır. UNESCO'nun yapmış olduğu açıklama bağlamında geçtiğimiz bahar döneminde öğrencilerin \% 90'ının okullarına devam edemediği ortaya konmuştur (2020). Dünya Sağlık Örgütü bu tedbirlerin bireyler arasındaki yakın sosyal mesafeyi ve etkileşimi en aza indirmek ve virüsün yayılımını önlemek için yapıldığını açıklamıştır (WHO, 2020). Son 50 yılda her bakımdan büyük gelişim gösteren eğitim sistemlerinin bu denli bir zorlukla karşılaşmadığı araştırmacılar tarafından dile getirilmektedir (Daniel, 2020). Bu durum, daha önce de belirtildiği gibi, bir acil durumdur ve çözümler bu doğrultuda ortaya konmuştur (Bozkurt, 2020; Bozkurt \& Sharma, 2020; Tümen Akyldız, 2020). Ancak eğitimciler bu dönemde yapılan uzaktan eğitim uygulamalarının yüz yüze eğitimin yerini tutamayacağını ve de öğretmen ve öğrenci bazında birçok sıkıntı yaşandığını belirtmektedirler (Atreya \& Acharya, 2020:419).

Bahsi geçen bu değişimlerin dil öğretim ortamlarına da yansıdığı açıktır. Yüz yüze öğretimin yapıldığı dil sınıflarının çevrim içi/uzaktan öğretim ortamlarına kolaylıkla dönüşebildiği bilinmektedir. Bilgisayar teknolojileri dil öğrenenlerin çok farklı ortamlardan aynı dil sınıfına erişimini sağlamaktadır. $\mathrm{Bu}$ durumda öğretmen ve öğrenenlerin bu teknolojileri özellikle de içinde bulunduğumuz acil çözüm durumları gibi durumlar için etkin bir şekilde kullanmaları gerekmektedir. Türkiye'de yabancı dil olarak İngilizce öğretimi uzun yıllardan beri araştırmalara konu olmuş ve bazı yönleriyle çözüme ulaştırılamamışbir durumdur (Bal, 2006; Özsevik, 2010; Paker, 2012). Yabancı dil olarak İngilizce öğrenimini etkileyen birçok faktör bulunmaktadır. Bunlar, öğretim ortamı, ebeveyn etkileri, öğretim yöntemleri gibi dış kaynaklı etmenler ve de konuya karşı duyulan ilgi, tutum, zekâ, öğrenme stili ve motivasyon gibi iç kaynaklı etmenlerdir (Fansury, vd., 2020). Türkiye'de yabancı dil öğretimi alanında yürütülen ortak çalışma sonrası, British Council ve TEPAV bu alandaki problemleri; yabancı dil öğretmenlerinin dil yeterlik potansiyellerinin sınıf performanslarına tam olarak yansımaması, öğretmen odaklı bir anlayış benimsenmesi, ders kitaplarına fazlaca bağımlı kalınması ve de öğrencilerin bireysel farklılıklarının sınıf için aktivitelerine yansıtılmaması şeklinde rapor etmiştir (2014). Ylllarını Türkiye'de yabancı dil öğretmekle geçirmiş bir uzmanın görüşüne göre Türkiye'de yabancı dil öğretilememe/ öğrenememe durumunun temel nedeni dilsel anlamdaki yetersizliktir

\footnotetext{
Adres $\mid$ Address

İstanbul Medeniyet Üniversitesi, Eğitim Bilimleri Fakültesi, Türkçe ve Sosyal Bilimler Eğitimi Bölümü, Türkçe Eğitimi ABD Cevizli $\quad$ Turkish and Social Scinces Education, Turkish Language Teaching Kampüsü, Kartal-İstanbul/TÜRKIYE $\quad$ Education, Cevizli Campus, Kartal-İstanbul /TURKEY e-posta: editor@rumelide.com $\mid$ e-mail: editor@rumelide.com
} 
(Osterloh, 1982, 165). Bu durumda yabancı dil öğretmenleri bir ülkenin dil gelişimine olduğu kadar bütünsel gelişimine de katkısı olan kişilerdir (König, 1989, 167). Yüz yüze sınıf ortamlarında mevcut problemleri yaşayan yabancı dil öğretmenlerinin küresel salgın döneminde bu problemlerle nasıl baş ettikleri ve karşılaştıkları güçlükler için geliştirdikleri çözüm önerilerini öğrenmek yeni uygulamalar için oldukça büyük önem taşımaktadır.

$\mathrm{Bu}$ noktadan hareketle, mevcut çalışmada sınıf ortamında yabancı dil olarak İngilizce öğretirken yaşanılan sorunlar; bilgi-iletişim teknolojileriyle ve de uzaktan eğitim yoluyla yabancı dil öğretimi açılanarak Covid-19 küresel salgını boyunca uzaktan eğitimle dil öğretimi yapan ve araştırmaya katılan İngilizce öğretmenlerin görüşlerinden elde edilen bulgular ve sonuçlar sırasıyla açıklanacaktır.

\section{Yabancı dil olarak İngilizce öğretimi}

Yabancı dil öğretimi ve iletişim becerileri birbirinden ayrılmaz iki kavramdır. Yabancı dilde yetkin olmak o dildeki iletişim becerilerini de yetkin bir şekilde kullanmak demektir (Littlewood, 1992). Ancak tek dilli toplumlarda sınıf dışı erek dile maruz kalmanın kısıtlı olduğu durumlarda, yabancı dil öğrenenler iletişim becerilerini tam olarak geliştirememektedirler (Bahrani \& Tam, 2011). Williams (2017) bu durumu Doğu Asya ülkelerinin ortak bir sorunu olarak ele almış ve de İngilizce öğretimindeki problemlerin, öğretimin öğretmen ve ders kitabı odaklı yapılmasından kaynaklandığını belirtmiştir. Ancak bir yabancı dil öğrenmek, o dilin sadece dil bilgisi kurallarını, cümle yapısını ve sözcüklerini öğrenmek değil; aynı zamanda bireyler arasında erek dilde iletişimi sağlamaktır (Zhou \& Griffiths, 2011). Yürütülen bir çalışmada, Avusturalya'da yabancı dil olarak İngilizce öğretimi, öğretmenlerin bakış açısıyla değerlendirilmiş ve iletişimsel dil öğretimi bağlamında, teoriyle uygulama arasında büyük fark olduğunu tespit edilmiştir (Sato ve Kleinsasser's, 1999). Bireylerin ancak erek dilde iletişim kurarak o dili tam anlamıyla öğrenebilecekleri bilinmektedir (Richards \& Rogers, 2001). Türkiye'deki problem de Avusturalya ve Doğu Asya ülkelerindeki problemlerden farksız değildir. Tek resmi dilli bir ülke olan Türkiye'de de öğrencilerin erek dili yabancı dil sınıfı dışındaki ortamlarda kullanma şansları oldukça azdır. Bu problem ülkemizde yıllardır süregelmektedir. Bal (2006) da Türkiye'deki İngilizce öğretmenlerinin dili iletişimsel bir yaklaşımla öğretmeleri gerektiğinin farkında olduklarını; ancak kalabalık sınıflar, öğretim programlarının yoğunluğu ve bu nedenle etkileşim azlığının bu yaklaşımın sınıf içinde uygulanmasını zorlaştırdığını dile getirmiştir. Özsevik (2010)ise bunlara ek olarak, öğretim programları ile sınav sistemi arasındaki uyumsuzluk, eksik iletişimsel beceriler ve öğretmen ve öğrencilerdeki düşük motivasyonun yabancı dil öğretiminde yaşanan problemler olduğunu belirtmiştir.. Kunnan (2005), eğitimin 'sınav için öğretme' ve dil öğrenme aktivitelerine daha az yer verme şeklinde yapılmasının olumsuz etkilerinden bahsetmiştir. Millî Ĕ̆itim Bakanlığı (2008) yaptığı revizyonla yabancı dil öğretiminin çoğunlukla iletişim becerilerini geliştirmek üzere yapılanması gerektiğini ortaya koyarak öğretim programlarını ve içeriklerini buna göre düzenlemiştir. Buradaki temel hedef, yabancı dil öğrencilerinde iletişimsel beceriyi eğitimin ilk kademesinden itibaren kazandırmaya çalışmaktır. İletişimsel anlamda yeterlik ancak öğretmenöğrenci, öğrenci-öğrenci arasında interaktif bir ortamın sağlanması yoluyla kazanılmaktadır (Silberstein, 2002). Yabancı dil sınıflarında bu interaktif iletişimin olmayışı ve sadece kurallar yoluyla öğretim yapılması istenilen bir durum değildir. Hedefin öğrencilere erek dilde iletişimsel yolla dil öğrenimini sağlamakken; Türkiye'de yapılan çalışmalar bu hedefin istenilen ölçüde gerçekleşmediğini göstermektedir (Paker, 2012; TEPAV, 2014).

Globalleşmenin ve hızlı teknolojik değişimlerin yaşandığı günümüzde, bu teknolojilerin yaşamın her alanına girmesi kaçınılmazdır. Teknoloji küreselleşmenin merkezindedir ve en çok etki gösterdiği alan

Adres 
da eğitimdir (Graddol, 1997). Yabancı dil öğretimi gibi bir ülkenin gelişimini etkileyen olgulardan birinin de bu değişimlere açık olması gerekmektedir. Covid-19 küresel salgını döneminde de teknolojik dönüşümün gerekliğieğitimciler tarafından kabul edilmiştir (Iivari, Sharma \& Venta Olkkonen, 2020). O hâlde teknolojik destekler ve uzaktan eğitim yoluyla yabancı dil öğrenimi konusunu incelemek faydalı olacaktır.

\section{Bilgi-iletişim teknolojileri ve uzaktan eğitim yoluyla yabancı dil öğretimi}

Teknolojinin yabancı dil öğretiminde kullanılması Covid-19 salgınından çok önceye dayanmaktadır. Teknoloji, öğrenme sürecini öğrenciler için çok daha zevkli hale getirmektedir. Günümüzde dijital içeriğin ve teknolojinin öğrenme sürecinde kullanımı geleneksel öğrenme ortamlarına bir alternatif olarak ele alınmakta (Alrubaie, vd., 2020) ve yeni bilgi alanları üreterek var olan yöntemleri değiştirmek için uygun zemini hazırlamaktadır (Pourhosein Gilakjani, 2013). Bilgisayar teknolojilerinin kullanımının eğitimde kaliteyi artırdığı pek çok öğretmen tarafından kabul gören bir görüştür (Becker, 2000). Bilgisayar, cep telefonu ve internet öğretme ve öğrenme sürecini etkili hale getiren teknolojilerdir (Ta'amneh, 2017).

Bilgi ve iletişim teknolojilerini eğitim ortamlarında kullanırken en büyük rol öğretmenlere düşmektedir. (Zhu, 2010). Öğretmenler teknoloji sayesinde öğrencileri de sürece dâhil ederek zaman kısıtlaması ve planlaması olmadan öğrenmeyi daha anlamlı hale getirebilirler (Rodinadze \& Zarbazoia, 2012). Bu nedenle İngilizce öğretmenlerinin son teknolojilerden ve de onların yabancı dil öğretirken nasıl daha etkili kullanıldığından haberdar olmaları gerekmektedir (Al-Mohammadi \& Derbel 2014). Zira yabancı dil öğretiminde yapılan araştırmalar da teknoloji kullanımının öğrenciler için pek çok fayda sağladığını ortaya koymaktadır. Yabancı dil öğrenirken teknoloji kullanımı öğrencilerin erek dile daha fazla maruz kalmalarını sağlamakta ve yabancı dili gerçek ortamında öğrenmelerine olanak sağlamaktadır. Teknoloji yoluyla bireyler sınıf ortamında ya da dışında yakalayamadıkları sosyal etkileşim şansını bulmakta ve de gerçek aktivitelerle diğer öğrencilerle iş birliği yapmaktadır (Warschauer, 2000; Parvin \& Salam, 2015). Cep telefonu uygulamalarından en yaygin kullanılan Whatsapp'ın yabancı dil öğretiminde etkili bir kullanım potansiyeli olduğu araştırılan konulardan biridir (Jasrial, 2018).Yapılan bir çalışmada Whatsapp uygulamalarının da yabancı dil öğretiminde öğrencilerin yazma, konuşma ve sözcük seçimi becerilerini geliştirdiği gözlemlenmiştir (Alsaleem, 2014). Manan da (2017) yürüttüğü deneysel çalışmada yabancı dil öğreniminde Whatsapp uygulamasının konuşma becerisini ve öğrencilerin öğrenme isteğini artırdığını ortaya koymuştur. Whatsapp uygulamasının öğretmen-veli iletişimini de olumlu yönde etkilediği ulaşılan araştırma sonuçlarından birisidir (Balcı \& Tezel Şahin, 2018).

Yukarıda bahsi geçen bilgi ve iletişim teknolojileri geleneksel yolla yapılan yabancı dil öğretimini farklı ortamlara taşıyabilmektedir. Yabancı dil öğretimi, sınıf ortamında bir öğretmenin bir grup öğrenciyle yüz yüze olmasını artık gerektirmemektedir. Bahsi geçen interaktif bilgi ve iletişim teknolojileri (bilgisayar, cep telefonları vs.) sayesinde yabancı dil öğrenenler uzaktan eğitim yoluyla yapılan derslere rahatlıkla katılabilmektedirler. Hibrit ya da tamamen uzaktan eğitimin tercih edilme nedenlerinin başında bu sistemlerin ekonomik olarak avantajlı oluşudur (Allen \& Seamen, 2014). Web-tabanlı uzaktan eğitimin bir avantajı da öğrenci ve öğretmene zaman ve planlamada esneklik sağlamasıdır (Smedley, 2010; Santana De Oliveira, vd., 2018). Bu esneklik sayesinde öğrenme geleneksel eğitim ortamlarının katı kurallarının dışına çıkabilmektedir. Uzaktan eğitim yoluyla dil öğretiminde yapılan araştırmalardan çıkan ortak bir sonuç bu yöntemin öğrencilerde güdülenmeyi artırmasıdır (Liu, vd., 2002; Ushida, 2005). Bu avantajların yanı sıra, uzaktan eğitim uygulamalarının

\footnotetext{
Adres $\mid$ Address

İstanbul Medeniyet Üniversitesi, Eğitim Bilimleri Fakültesi, Türkçe İstanbul Medeniyet University, Faculty of Education Sciences, ve Sosyal Bilimler Eğitimi Bölümü, Türkçe Eğitimi ABD Cevizli Turkish and Social Scinces Education, Turkish Language Teaching Kampüsü, Kartal-İstanbul/TÜRKIYE $\quad$ Education, Cevizli Campus, Kartal-İstanbul /TURKEY e-posta: editor@rumelide.com 1 e-mail: editor@rumelide.com
} 
bazı dezavantajları da bulunmaktadır. Bunlardan en önemlilerinden birisi teknik bir eksiklik olan uzaktan eğitimle yabancı dil öğretirken öğrencilerdeki teçhizat ve internet eksikliğidir. Bu durum öğrencilerde öğrenme bağlamında eşitsizliğe neden olmaktadır (Jolliffe, vd., 2001). Uzaktan eğitimin bir başka olumsuzluğu ise öğretmen-öğrenci ve öğrenci-öğrenci etkileşimini ve iletişimini azaltmasıdır (Young, 1997). Russel ve Curtis (2013) özellikle kalabalık sınıf ortamlarında etkileşim ve iletişim sıkıntısı yaşandığını rapor etmiştir. Bu da yabancı dil öğretiminde olmazsa olmaz olan etkileşimi azalttığı için verimi düşürebilmektedir. Uzaktan eğitimle yapılan yabancı dil öğretiminde gözlemlenen başka bir olumsuz durum da bu sisteme ilk başta yabancı olan öğrencilerde kaygıya neden olmasıdır (Ushida, 2005).

Olumlu ve olumsuz yönleriyle masaya yatırıldığında, 21 yüzyıl bilgiye ve teknolojiye ulaşmanın oldukça kolay olduğu bir çağdır. Zaman/mekân kısıtlaması olmadan, öğrenme esnekliği sağlayan ve süreçte, öğrenciyi merkeze alarak, onu bireysel ve yetkin öğrenen haline dönüştüren uzaktan eğitim sisteminden en yüksek düzeyde verim alacak şekilde öğrencilerin ve öğretmenlerin bilinçlendirilmesi gerekmektedir.

\section{Araştırmanın önemi, amacı ve araştırma soruları}

Yabancı dil öğretimi teknolojik olanaklardan yararlanılabilecek elverişli bir alandır. Ancak Covid-19 küresel salgınının kendi iç dinamikleri ve zor şartları nedeniyle geleneksel sınıf ortamlarında uygulanabilecek tüm etkinliklerin yapılamamış olması beklenilen bir sonuçtur. Yine de yabancı dil öğretiminde yaşanan sorunların Covid-19 küresel salgını döneminde hangi boyutta olduğu merak konusudur. Küresel salgın nedeniyle yaşanan belirsizlikler uzaktan eğitim sürecinin de bir müddet daha uzayabileceğini işaret ederken bu dönemde öğretimi devam ettirmek zorunda olan ve zorlukları göğüsleyen öğretmenlerimize çok iş düşmektedir. Bu noktadan hareketle yabancı dil öğretmenlerinin süreç hakkındaki görüşleri ve problemli durumlar için ürettikleri çözüm önerileri yeni uzaktan eğitim uygulam için büyük önem arz etmektedir. Yapılan alan taramasında dünyada Covid-19 pandemisi sırasında yabancı dil öğretimine dair yapılan çalışmaların bulunduğu (Yi \& Jang, 2020; Türkiye'de ise yabancı dil öğretmen adaylarının dil becerilerinin bu süreçten nasıl etkilendiğini araştıran bir araştırmanın mevcut olduğu (Öztürk Karataş \& Tuncer, 2020) görülmüştür. Ancak, Covid-19 küresel salgını döneminde yabancı dil öğretmenlerinin deneyimlerine ve önerilerine yer veren bir çalışmaya rastlanmamıştır. Bu nedenle araştırma alana önemli katkılar sağlayacak niteliktedir.

$\mathrm{Bu}$ noktadan hareketle mevcut araştırma yabancı dil öğretmenlerinin Covid-19 küresel salgını sürecinde yapılan uzaktan eğitim uygulamalarına dair görüşlerini, yaşadıkları problemleri ve bu problemlere getirdikleri çözüm önerilerini ortaya koymayı amaçlamıştır. Bu amaçlara hizmet etmek üzere araştırma soruları aşağıdaki gibi oluşturulmuştur:

1-Covid-19 küresel salgın döneminde yabancı dil öğretiminde yapmış olduğunuz uzaktan eğitim çalışmaları nelerdir?

2- Bu dönemde ders öncesi, ders süresi ve sonrasında karşlaşmış olduğunuz problemler nelerdir?

3-Gelecek dönemlerde yapılacak uzaktan eğitim uygulamaları için mevcut problemlere çözüm önerileriniz nelerdir?

\section{Yöntem}

Nitel sosyal araştırmalar, diğerlerinin yaşadığı deneyimler, problemler ve düşüncelerden yola çıkarak okuyucuya benzer durumlarla nasıl daha rahat baş edilebileceğini gösterir (Silverman, 2010). Bu

\footnotetext{
\begin{tabular}{r|l} 
Adres & $\begin{array}{l}\text { Address } \\
\text { İstanbul Medeniyet Üniversitesi, Eğitim Bilimleri Fakültesi, Türkçe }\end{array}$ \\
İstanbul Medeniyet University, Faculty of Education Sciences,
\end{tabular} ve Sosyal Bilimler Eğitimi Bölümü, Türkçe Eğitimi ABD Cevizli $\quad$ Turkish and Social Scinces Education, Turkish Language Teaching Kampüsü, Kartal-İstanbul/TÜRKIYY $\quad$ Education, Cevizli Campus, Kartal-İstanbul /TURKEY e-posta: editor@rumelide.com 1 e-mail: editor@rumelide.com
} 
durumda diğer insanların yaşadığı deneyimler ve onların yansıması temel alınmaktadır (Lincoln \& Guba, 1985). Bu görüşlerden hareketle mevcut çalışma nitel bir çalışma olarak tasarlanmıştır. Araştırma verileri odak grup tartışması tekniğiyle toplanmıştır. Odak grup görüşmelerinde bir katılımcının ortaya koyduğu bir düşünce diğerleri tarafından geliştirilebilmekte, bu sayede olaylara daha geniş bir bakış açısı kazandırılabilmektedir (Krueger, 1994). Bu teknikle elde edilen verilerin bire bir görüşmelerden elde edilen verilerle karşlaştırıldığında daha derinlemesine ortaya konduğu görülmüştür. Bu durumun nedeni grup üyeleri arasındaki karşılıklı etkileşimdir (Thomas, vd., 1995).

Bir nitel araştırma güvenirliği doğrultusunda değer kazanmaktadır (Fossey, vd., 2002). Bu nedenle mevcut araştırmada geçerlik ve güvenirliği sağlamak için Guba'nın (1980) gerekli gördüğü bir dizi ölçüt sağlanmaya çalışılmıştır. Bunlar sırasıyla:

Güvenirlik: Bir araştırmanın güvenilir kabul edilmesinin temel şartlarından biri Lincoln ve Guba' nın (1985) önerdiği katılımcı kontrolüdür. Araştırmacı, bu nedenle çalışmadan elde ettiği bulguları ilk olarak katılımcılarıyla paylaşmış ve de herhangi bir değişiklik talep edip etmediklerinden emin olduktan sonra, bulgularına son şeklini vermiştir.

Shenton (2004) araştırmanın güvenirliği için katılımcılara çalışmaya katılmayı reddetme hakkının verilmesi gerektiğini öne sürmüştür. Bu çalışmaya katılan yabancı dil öğretmenleri tamamıyla gönüllülük esası ile seçilmiştir. Bu durumun güvenirliği artırdığı düşünülmektedir.

Bulgular aktarılırken direkt alıntılara yer verilmesi (Shenton, 2004) de güvenirlik için yerine getirilmesi gereken ölçütlerden bir başkasıdır. Araştırmacı bulgularını ortaya koyarken katılımcıların söylemlerini hiçbir değişikliğe uğratmadan sunmuştur.

Aktarılabilme: Nitel araştırmalarda aktarılabilme özelliği, sonuçların benzer çalışmalara genellenebilmesidir.,(Merriam, 1998). Araştırmacı, tüm araştırma sürecini detaylarıyla anlatarak okuyucunun benzer durumlara genelleme yapmasina olanak vermektedir (Guba, 1981). Bu nedenle mevcut araştırmada tüm araştırma süreci detaylarıyla verilmiştir.

Doğrulanma: Araştırma sonuçlarının farklı araştırmacılar tarafından doğrulanması güvenirlik açısından önemlidir (Baxter \& Eyles, 1997). Bu nedenle araştırmada nesnelliği sağlamak için, hem araştırma soruları hem de verilerin analizinden elde edilen bulgular, Eğitim Fakültesinde farklı bölümlerde görev yapan iki akademisyen tarafından da doğrulanmıştır.

\section{Araştırmanın katılımcıları}

Araştırmanın altı katılımcısı Elazı̆̆ ilinde ortaokul düzeyinde İngilizce öğretmenliği yapmaktadır. Odak grup tartışmalarında katılımcıların konuya yeterli düzeyde odaklanabilmek noktasında tartışılacak alanda yeterli bilgiye sahip olması beklenmektedir (Burrows \& Kendal, 1997). Katılımcılar 2019-2020 eğitim-öğretim yllında Covid-19 pandemi döneminde İngilizce öğretmenliği yapmış olup; uzaktan eğitim çalışmaları ile ilgili benzer deneyimlere sahiptirler. Katılımcılarla ilgili gerekli bilgiler aşağıdaki tabloda verilmiştir.

\footnotetext{
Adres $\mid$ Address

İstanbul Medeniyet Üniversitesi, Eğitim Bilimleri Fakültesi, Türkçe İstanbul Medeniyet University, Faculty of Education Sciences, ve Sosyal Bilimler Eğitimi Bölümü, Türkce Eğitimi ABD Cevizli Turkish and Social Scinces Education, Turkish Language Teaching Kampüsü, Kartal-İstanbul/TÜRKIYE $\quad$ Education, Cevizli Campus, Kartal-İstanbul /TURKEY e-posta: editor@rumelide.com 1 e-mail: editor@rumelide.com
} 
Tablo 1: Katılımcıların demografik özellikleri

\begin{tabular}{llll}
\hline Katılımci $^{*}$ & Cinsiyet & $\begin{array}{l}\text { Öğretmenlik Deneyimi } \\
\text { (yıl) }\end{array}$ & $\begin{array}{l}\text { Mezun Olunan Bölüm } \\
1(\mathrm{E} 2)\end{array}$ \\
$2(\mathrm{D} 7)$ & 2 & İngilizce Öğretmenliği \\
$3\left(\mathrm{~S}_{3}\right)$ & $\mathrm{K}$ & 7 & İngilizce Öğretmenliği \\
$4(\mathrm{~V} 5)$ & $\mathrm{E}$ & 3 & İngilizce Öğretmenliği \\
$5(\mathrm{~S} 13)$ & $\mathrm{K}$ & 5 & İngiliz Dili ve Edebiyatı \\
$6(\mathrm{C} 2)$ & $\mathrm{K}$ & 13 & İngilizce Öğretmenliği \\
\hline
\end{tabular}

*Bulgular kısmında direkt aktarım yaparken kullanılacak olan kodlar da tabloda verilmiş olup kişisel bilgileri muhafaza etmek için katılımının isminin baş harfi ve meslekteki deneyim süresi kullanılarak belirlenmiştir.

\section{Veri toplama süreci}

Odak grup tartışması, az sayıda insanı gayri resmî bir ortamda bir araya getirip, belirli bir konuya odaklanmalarını sağlayıp fikirlerini ifade etmelerini amaçlayan bir veri toplama türüdür (Wilkinson, 2015, 119). Bu yöntem, araştırmacıya grup dinamikleri ve etkileşimi sayesinde katılımcıların belirli bir konu hakkındaki bakış açılarını derinlemesine anlaması noktasında yardımcı olur (Lauri, 2019). Birebir yapılan görüşmelerin aksine bu teknik, katılımcılara diğerlerini dinleme, onlarla etkileşime girme ve başka fikirlere saygılı olma konusunda yol göstermekte ve insanların sesli düşünmelerini sağlamaktadır (Far, vd., 1996). Bu araştırma için odak grup tartışma tekniğinin tercih edilme nedenlerinde biri sosyal mesafeyi korumak isteyen katılımcllara, toplantıyı uzaktan teknolojik aletler yardımıyla gerçekleştirebilme olanağı sunduğu için rahatlık sağlamasıdır. Veriler Whatsapp uygulamasının görüntülü toplu görüşme özelliği yoluyla toplanmıştır. Bu tekniği kullanmanın ifkinci avantajı, araştırmacının toplantı başkanı olarak katılımı noktasında uygunluğudur. Zira araştırmacı da bahsi geçen süreçte uzaktan eğitim yoluyla derslerini yürütmüş olup, sürece hâkimdir. Grup üyelerinin birbirlerini tanıyor olmaları odak grup görüşmesi için bir avantaj teşkil etmektedir (Kitzinger, 1994). Katılımcllar daha önceden bölge ya da il zümrelerinde bir araya gelmiş olup birbirlerini şahsen tanımaktadırlar. Araştırmacının başkanlığını yapmış olduğu çalışmada kendi yüksek lisans öğrencisi de rapor yazıcı olarak not tutmuş ve gerekli yerlerde tartışmaya müdahil olmuştur. Araştırmacı toplantı başladığında öğretmenlere kendilerini tanıtmalarını ve de rahat hissetmelerini sağlayıcı sorular sormuş bu yolla katılımcıların birbirleriyle etkileşime geçmiştir. Daha sonra hazırlanmış olan sorular aynı sırayla tüm katılımcılara sorulmuş ve gerekli görülen yerlerde yanal sorular sorulmuştur. Toplantı yaklaşık bir buçuk saat sürmüş ve kayıt altına alınmıştır. Toplantının hemen ardından rapor yazıcı ve araştırmacı notlarını birleştirmiş ve kayıtlar yazıya dökülmüştür.

\section{Veri analizi}

Whatsapp grup görüşmesi yoluyla elde edilen veriler içerik analizi uygulanarak çözümlenmiştir. İçerik analizi teorik konunun derinlemesine anlaşılmasını ve yazılı verinin kategorilere ayrılmasını sağlar (Cavanagh, 1997). İçerik analizinde Berg (2001) tarafından önerilen dört basamak izlenmiştir. Araştırmacı ilk olarak verileri anlamlandırmış, içeriğini belirlemiş, içerikten homojen yapıda kodlar oluşturmuş ve son olarak da tekrar edilme sıklıklarını belirterek gerçekçi sonuçlara ulaşmıştır.

Adres

İstanbul Medeniyet Üniversitesi, Eğitim Bilimleri Fakültesi, Türkçe ve Sosyal Bilimler Eğitimi Bölümü, Türkçe Eğitimi ABD Cevizli Kampüsü, Kartal-İstanbul/TÜRKIYY e-posta: editor@rumelide.com 


\section{Bulgular}

Elde edilen verilerin analiziyle ulaşılan bulgular her bir araştırma sorusunu takiben verilmiştir.

\section{Araştırma sorusu}

Tablo 2: İngilizce öğretmenlerinin uzaktan eğitim uygulamaları

\begin{tabular}{ll}
\hline Kod & f \\
\hline Eğitim Bilişim Ağı (EBA) üzerinden doküman & 6 \\
EBA üzerinden çevrim içi ders & 4 \\
Whatsapp grupları yoluyla doküman & 4 \\
\hline
\end{tabular}

İlk araştırma sorusu kapsamında elde edilen bulgular Tablo 2'de verilmiştir. Katılımcılara salgın döneminde yürütmüş oldukları uzaktan eğitim çalışmaları sorulduğunda tüm katılımcılar EBA sistemi üzerinden doküman ve ödev yüklediklerini; beşi EBA sistemi devreye girmeden Whatsapp uygulaması yoluyla sınıf grupları oluşturarak doküman ve ödev paylaştı̆̆ını ve yine katılımcılardan beşi sistem devreye girdikten sonra çevrim içi ders yaptıklarını belirtmişlerdir. Millı̂ Eğitim Bakanlığı'nın sistemi uygulamaya açmasının ardından ödev ve doküman yüklediklerini ve bu durumun okul idaresi tarafından kontrol edildiğini bildirdiler. Aynı sistemin çevrim içi derslere açılmasıyla katılımcıların dördü bu sistemi kullandıklarını dile getirdi. V5 “...özellikle sınava girecek olan 8. sinıflarımla dersleri düzenli yürüttüm, diğer sinıflar için sadece ödev ve doküman yükledim”, yorumunda bulunurken; $\mathrm{C} 2$ ise "Pandemi dönemini köyde ailemle geçirdiğim için teknolojik olanaklarm sinurlıyd, internet problemim vard, bu nedenle sadece bir kez çevrim içi ders yaptım. Zümre arkadaşımdan rica ettim o benim yerime özellikle 8. Sinflartma ders yaptı. Ben de whatsapp grubundan doküman ve ödev göndererek onlara destek olmaya çalıştım.” Demiştir. Bu durumda öğretmenlerin de içinde bulundukları koşullar doğrultusunda sisteme dâhil oldukları sonucu ortaya çıkmıştır. Whatsapp grupları katılımcı öğretmenlerimizin en çok tercih ettikleri iletişim aracı olmuştur. Dört öğretmen EBA süreci başlamadan gruplarını oluşturduklarını ve oradan doküman ve ödev paylaştıklarını belirtmiştir. S13 “özellikle LGS sinavina girecek olan öğrencilerime Whatsapp yoluyla doküman paylaştım. Yaptığım en faydalı şey bu süreçte öğrencilerimin İngilizce kitap okumasım sağlamak oldu. Bu gruplar yoluyla onları kitap okumaların takip edebildim. Bu durum öğrencileri de kendi içlerinde motive etti." şeklinde öğrencileri motive edebildiğini hatta bu şekilde İngilizce seviyelerindeki artışı gözlemleyebildiğini ifade ederken D5 ise "öğrenciler salgın sürecinin başında çok paniklediler. Özellikle sınava girecek olanlar çok endişelendiler. Bu grupları oluşturunca biraz rahatladılar ve bu gruplar yoluyla öğrencilerime testler ve deneme sinavları gönderdim. Bunlarn yanı sira, gruplarda öğrencilerimi kelime oyunu uygulamalarına yönlendirdim.” şeklinde bu uygulamadan yararlandığını ifade etmiştir.

\section{Araştırma sorusu}

Tablo3: Uzaktan eğitim sürecindeki problemler

\begin{tabular}{lll}
\hline Kategori & Kod & f \\
\hline Öğrenci-kaynaklı Problemler & Motivasyon düşüklüğü & 6 \\
& Çalışmaya karşı isteksizlik & 5 \\
& Bireysel öğrenmeyi bilmeme & 4 \\
\hline
\end{tabular}

Adres

İstanbul Medeniyet Üniversitesi, Eğitim Bilimleri Fakültesi, Türkçe ve Sosyal Bilimler Eğitimi Bölümü, Türkçe Eğitimi ABD Cevizli Kampüsü, Kartal-İstanbul/TÜRKIYE e-posta: editor@rumelide.com
Address

İstanbul Medeniyet University, Faculty of Education Sciences,

Turkish and Social Scinces Education, Turkish Language Teaching

Education, Cevizli Campus, Kartal-İstanbul /TURKEY

e-mail: editor@rumelide.com 


\begin{tabular}{lll}
\hline Teknoloji-kaynaklı Problemler & İnternet sıkıntısı & 6 \\
& Teknolojik araçların yetersizliği & 6 \\
Öğretmen-kaynaklı Problemler & Uzaktan eğitim sistemini bilmeme & 4 \\
& Kişisel problemler & 2 \\
& Teknoloji alanında bilgi eksikliği & 2 \\
Veli-kaynaklı problemler & Uzaktan eğitim sistemini bilmeme & 4 \\
& Öğrenciyi teşvik edememe & 2 \\
& Ekonomik sıkıntılar & 2 \\
Toplam & & 43 \\
\hline
\end{tabular}

Çalışmaya katılan öğretmenlerin Covid-19 küresel salgın dönemindeki uzaktan eğitim sürecinde en çok karşılaştıkları problemler öğrencilerden kaynaklı problemler olarak belirtilmiştir ( $\mathrm{F}=15)$. Öğretmenlerin hepsi tarafından öğrencilerdeki motivasyon düşüklüğü bu kategori altındaki ilk kodu oluşturmuş̧tur. E2 “Öğrencilerin isteksiz oluşu süreci en olumsuz etkileyen faktördü” şeklinde yorum yaparken V5 "Illk etapta hevesle başlayanlarm bile sürecin sonuna doğru motivasyonlarmmn düştüğünü derslere bile katılmadıkların gözlemledim. Hatta çok başarılı öğrencilerim bile bu süreçte motivasyon kaybı yaşadılar. Bu durum benim öğretimime de yansıdı.” yorumunu yapmıştır. Öğrencilerde çalışmaya karşı bir isteksizlik olduğunu belirten katılımcılardan (F=5) S2 "Öğrencilerde zaten var olan yeterli çalş̧mama durumu süreçte daha belirgin hale geldi. Kontrol mekanizması ve otorite olarak gördükleri öğretmen ve değerlendirme sistemi olmayınca öğrenciler çalışmayı bıraktılar." diyerek durumdan duyduğu rahatsızlığı dile getirmiştir. Bu kategorinin son kodu öğrencilerin kendi başlarına öğrenme konusunda yetersiz oluşlarıdır $(\mathrm{F}=4) . \mathrm{V}_{5}$ "Öğgrenciler her şeyi öğretmenden bekliyor. Siz onlara öğretmek, yol göstermek ve onlarl güdülemek zorundasinzz. Öğretmen, sadece ekran karşısında kendisine ayrlan zaman diliminde ders anlatan bir araç haline dönüşünce öğrenciler afalladı. Hâlbuki uzaktan eğitim bu anlamda öğrenciye kendi öğrenme ortamın sunma açısından güzel bir deneyim olabilirdi." derken E2 kendi yabancı dil öğreniminden yola çlkarak bir örnekle konuya açıllı getirmiştir “Almanca öğrenirken Youtube videoları izliyordum ve bu şekilde dil öğrenmeye çalsşıyordum. Bu tabii ki çok kolay bir süreç değil, bir yol gösterici gerekiyor. Öğrencilere kitabı verip al bunu tek başına öğren diyemeyiz tabii ki ancak onlara yol gösterip kendi öğrenmelerini kolaylaştırabiliriz.”

Teknoloji kaynaklı problemleri dillendiren katılımcıların $(\mathrm{F}=6)$ üzerinde en çok yorum yaptıkları kod süreçte hem kendilerinde hem de öğrencilerde var olan internete erişim ve internet kotası sıkıntısıdır. S3 "öğrencilerin çoğunun internet sıkıntısı olduğu için derslere devam edemediler" yorumunu yaparken $\mathrm{C}_{2}$ "süreci köyde geçirdiğim için internete ulaşımım çok sıkıntılıydı ve benden istenen çevrim içi dersleri bile yapamadım." şeklinde kendi sıkıntısını anlatan yorumu paylaşmıştır. Öğrencilerde teknolojik olarak gerekli bazı cihazların bulunmayışı bu kategorinin ikinci kodunu oluşturmaktadır. Öğrencilerinin birçoğunun toplumsal ve ekonomik düzeylerinin düşük olması dolayısıyla cep telefonlarının ve de bilgisayarlarının bulunmadığına dikkate çeken öğretmenlerden S13 "Çevrim içi ders yaptım ama katılım çok çok az oldu. Öğrencilerimin birçoğunun bilgisayarı yoktu, sokağa çıkmanın ve sosyal olarak birbirine yaklaşmanin zor olduğu bir dönem olduğu için internet kafeler ya da tanıdıklarının evlerini de kullanamadılar." şeklinde durumu izah etmiştir.

Öğretmen-kaynaklı problemler kategorisi altında en çok dile getirilen durum, öğretmenlerin uzaktan eğitim sistemini tam olarak bilmemesidir. E2 "Eğitim Fakültesi mezunuyum ve lisans dönemimde

\footnotetext{
Adres $\mid$ Address

İstanbul Medeniyet Üniversitesi, Eğitim Bilimleri Fakültesi, Türkçe İstanbul Medeniyet University, Faculty of Education Sciences, ve Sosyal Bilimler Eğitimi Bölümü, Türkçe Eğitimi ABD Cevizli Turkish and Social Scinces Education, Turkish Language Teaching Kampüsü, Kartal-İstanbul/TÜRKIYE $\quad$ Education, Cevizli Campus, Kartal-İstanbul /TURKEY e-posta: editor@rumelide.com 1 e-mail: editor@rumelide.com
} 
teknoloji dersi almama rağmen uzaktan eğitim nasıl yapılır neler yapmalıyım bilemedim. Birden kendimi bu sistemin içinde bulunca bocaladım. Öğrencilerimle fiziksel temas ve göz teması kurarak, jest ve mimiklerimi çok kullanarak bir şeyler öğretmeyi benimsemiş bir öğretmen olarak ilk etapta sadece doküman yüklemek sonra da ekran karşısında 5 saat işlemem gereken dersi 1 saate sığdırmaya çalışarak çok zorlandım.” Diyerek uzaktan eğitimi daha iyi bilmesi gerektiğini vurgulamıştır. V5 "Ben Eğitim Fakültesi mezunu değilim İngiliz Dili ve Edebiyatı Bölümü mezunuyum. Bu durumdan kaynaklı zorlandığımı düşündüm açıkçası ama şimdi diğer arkadaşları duyunca bunun fakülte farkı olmadiğını anladım. Teknolojiyle aram iyi olmasına rağmen, ben de uzaktan eğitimin inceliklerini bilmediğimi ve bu durumda yetersiz kaldiğımı hissediyorum." yorumunu yapmıştır. Katılımcılardan ikisi, kişisel bazı problemlerinden dolayı süreçte zorlandıklarını ifade etmişlerdir. S13 "Evde ilgilenmem gereken iki küçük çocuğum var. Bu dönemde onlar da okula ya da kreşe gidemedikleri için ve de ben eve bakıcı çağıramadığım için bazı sorumluluklarımı yerine getirirken oldukça zorlandım." Şeklinde problemini ifade ederken, bir diğeri D7 "Diğer öğretmenlerle ve idareyle yaşadığım bazı problemler oldu, bu problemleri maalesef öğrencilerime ders yapmayarak yansittım. Bu da uzaktan eğitim sisteminde benden kaynakh bazı sorunlara neden odu." Şeklinde özeleştiride bulunmuştur. Son kod olan teknolojik alandaki yetersizlikler için D7 "Teknoloji okuryazarlı̆̆ ve kullanımı alanında desteğe ihtiyacım var." diyerek öğretmenlerin bu alanda destek duyduklarını dile getirmiştir.

Son kategori velilerden kaynaklanan problemlerdir. Bu kategoride en sik yorum yapılan konu velilerin de uzaktan eğitim sistemini tam olarak bilmeyişleridir. S13 "Veliler bu sistemde aslinda çok önemli bir role sahiptiler. En azından verdiğimiz ödevler noktasında evde kontrol sağlayarak bize destek olmaları gerekiyordu. Ancak uzaktan eğitim sisteminin nasıl olması gerektiğini tam olarak bilmedikleri için, tüm sorumluluğu öğretmene brrakıp sadece şikâyet ettiler.” yorumuyla durumdan duyduğu sıkıntıyı dile getirmiştir. $\mathrm{C} 2$ ise "Evlerde yaratılan ciddiyetsiz öğrenme ortamı eğitime balta vurdu diyebilirim." demiştir. V5 ise öğrencilerin veliler tarafından teşvik edilmeleri gerektiğin şu şekilde belirtmiştir "Velilerin evde öğrenciyi güdüleyerek ders çalışmaya teşvik etmesi gerekiyordu. Verdiğimiz kelimeleri ezberlediklerini ya da ödevleri yapıp yapmadıklarm kontrol etmelerini istiyordum. Çünkü onu kontrol edecek bir zamanımı yoktu. Sadece 1 saat ders yapllnca o zamanı dolu dolu kullanmak istiyordum. Ama veliler öğrencileri bu konuda hiç teşvik etmediler. Esasında, sağlık açısından çok tedirgin olunan bu dönemde eğitim ikinci plana atılmış olabilir.” C2 velilerin pandemi döneminde yaşadıkları ekonomik sıkıntılardan kaynaklanarak çocuklarının eğitim konusuna yeterince eğilemediklerini belirtmiş ve şu şekilde yorum yapmıştır "Ekonomik sıkıntı yaşayan velilerim çoktu. Böylesine stresli bir dönemde onlara bir de çocukları motive edin, ödevlerini kontrol edin diyemedim. Bunu yapacak durumları olduğunu düşünmüyordum zaten."

\section{Araştırma sorusu:}

Tablo 4: Öğretmenlerin gelecek uygulamalar için çözüm önerileri

\begin{tabular}{lll}
\hline Kategori & Kod & f \\
\hline & Uzaktan eğitim seminerleri & 6 \\
& Dijital yetkinlikleri geliştirme & 5 \\
Öğretmenler İçin Öneriler & Yöntem ve teknikleri uzaktan & 4 \\
& eğitime uyarlama & \\
& Ölçme-değerlendirme & 4 \\
& Duyuşsal alana hitap etme & 3 \\
\hline
\end{tabular}

Adres 


\begin{tabular}{lll}
\hline & Pilot uygulamalar & 1 \\
& Bireysel öğrenmeyi öğrenme & 4 \\
Öğrenciler İçin Öneriler & Teknolojiyi öğrenmeye dâhil etme & 3 \\
& Motivasyon desteği & 3 \\
Veliler İçin Öneriler & Velilerle sıkı iletişim & 5 \\
& Velileri bilgilendirme & 3 \\
& Uygun çalışma ortamı yaratma & 1 \\
Teknolojik Anlamda Öneriler & Teknoloji ve internet desteği & 6 \\
Toplam & & 48 \\
\hline
\end{tabular}

Katılımcılar en çok değişimin öğretmen bazında olması gerektiğine inanmaktadırlar. Katılımcıların hepsi $(\mathrm{F}=6)$ öğretmenlerin lisans dönemleri sırasında yeterli uzaktan eğitim dersi almamasından kaynaklı bu sistemin temel ilkelerini ve süreçte öğrenci-öğretmen etkileşimini nassl sürdürmeleri gerektiğini bilmediklerini belirtmişlerdir. D7 "Bakanlk tarafindan duyurulan ve British Council ve bir yabancı kitap firması tarafindan organize edilen uzaktan eğitim seminerine katıldım. Ancak pek faydah bulmadım. Uzaktan eğitimin temel ilkeleri yerine, dil öğretim teknikleri üzerinde durdular. Biz farkh dil öğretim yöntem ve tekniklerini zaten biliyoruz ancak uzaktan eğitim esnasinda öğrencilerle nasıl daha iyi iletişim kuracağımızı, onları nasıl motive edeceğimizi, dersleri nasıl daha keyifli hale getireceğimizi ve bu süreçte öğrencilere uzaktan nasll İngilizce öğreteceğimizi anlatan, uygulamal eğitimlere ihtiyaç duyuyoruz. Bu tip seminerler ve eğitimler uzunca bir süre devam etmeli. Zira bundan sonra derslerin bir kısmı hep uzaktan yapılabilir." şeklinde eğitime ne denli ihtiyaç duyulduğunu belirtmiştir. İkinci kod olarak öğretmenlerin dijital yetkinliklerinin geliştirilmesi $(\mathrm{F}=5)$ önerisinde bulunulmuştur. S3 "Dijital olarak ben kendimi yeterli görüyorum ama özellikle yaşı daha ileri ve dijital ortamlara rahat ayak uyduramayan meslektaşlarımız için dijital anlamda yetkinlik kazandırmaya yönelik eğitim ve çalıştaylar düzenlenebilir." önerisinde bulunmuştur. Üçüncü kod olarak, yabancı dil sınıflarında uygulanan yöntem ve tekniklerin uzaktan eğitime göre uyarlanması oluşmuştur. Katılımcılar $(\mathrm{F}=4)$ sınıfta yüz-yüze ders işlerken uyguladıkları yöntem ve tekniklerden olduğu gibi yararlanamadıklarını ve bunları yenileyerek uygulamaları gerekeceğini belirtmişlerdir. E2 "Ben fiziksel etkileşimi derslerimde çok kullanırım. Bu sistemde bilgisayarm karşısında olup öğrencilerimle göz teması kuramadığım için ilk etapta çok zorlandım. Sonra farkh bir şeyler yapmam gerektiğini anladım. Evimi bu amaçla kullanmaya başladım. Örneğin, mutfağımın duvarlarına farkh resimler astım. Dersi mutfakta yaptım. Öğrencilerim bu resimlerdeki kelimeleri bulmaya çalıştılar. Sinıf ortamını evde yaratmaya çalıştım. Öğretmenlerin yapması gereken de bu. Ekran karşısına geçip anlatılacak bir ders değil İngilizce. İnteraktif ortam olmadan öğrencilerin öğrendikleri dilde iletişim kurmaların bekleyemeyiz. Bu interaktif ortamı yaratacak şekilde yöntemler ve teknikler uygulamahyız." derken, V5 "Ben çok verimli ders yaptığımı söyleyemem. Sadece 8. sinfflar sinav hazırlhğında oldukları için onlarla soru çözümleri üzerinde durdum. Ama diğer simflartma sadece doküman yükledim. Bir dahaki döneme bu durum böyle olmayacak. Öğrencilerimi derse dâhil edeceğim aktiviteler bulacağım. Daha uygun yöntemler kullanmaya çalışacağım. Bu durum bu şekilde devam eder ve biz uzaktan eğitim yapmaya devam edersek öğrenciler İngilizce dersinden kopacaklar yoksa. Sinıfta uyguladı̆̆ımı yöntemleri farklılaştırıp ekran karşısında da onlarm dikkatlerini çekecek şekilde ve de bireysel farkhlıklarmı gözeterek uygulamahyız." demiştir. Özellikle iletişimsel yaklaşımla ders yaptığını vurgulayan S3 "öğrenci odakh ve iletişimsel yolla devam ettirdiğim öğretimimi ben diğer arkadaşımın aksine,

\footnotetext{
Adres $\mid$ Address

İstanbul Medeniyet Üniversitesi, Eğitim Bilimleri Fakültesi, Türkçe İstanbul Medeniyet University, Faculty of Education Sciences, ve Sosyal Bilimler Eğitimi Bölümü, Türkce Eğitimi ABD Cevizli Turkish and Social Scinces Education, Turkish Language Teaching Kampüsü, Kartal-İstanbul/TÜRKIYE $\quad$ Education, Cevizli Campus, Kartal-İstanbul /TURKEY e-posta: editor@rumelide.com 1 e-mail: editor@rumelide.com
} 
fiziksel etkileşime ihtiyaç duymadan da devam ettirebilirim. Ancak ders saatlerimiz 3 saatten 1 e düşürüldüğü için sadece konu yetiştirme derdine düşüp iletişimden uzaklaşıyordum. Bu durumun çözüme kavuşturulmasın ve derslerimizin yine iletişimsel olarak devam etmesi gerekir.” yorumunda bulunmuştur. Ölçme değerlendirme olmadan öğrencilerin derse devamı sağlayamayacaklarını dile getiren öğretmenlerden V5 "Hepimiz kabul etmeliyiz ki öğrenciler için sinavlardan alacakları notlar önemlidir. Biz sistemden değerlendirmeyi çıkarırsak öğrencileri ekran karşısında tutamayız. Önümüzdeki dönemde de bu sistem kullanlacaksa eğer mutlaka ödev ya da çevrim içi sinavlar yoluyla öğrenciler değerlendirilmeye tabi tutulmahdır.” yorumunu yapmıştır. Mevcut araştırmanın katılımcılarından bir kısmı ( $\mathrm{F}=3$ ) duyuşsal alanın uzaktan eğitim sürecinde de oldukça önemli bir yeri olduğunu ve bu alana hitap edilecek uygulamaların yapılması gerektiği üzerinde durmuşlardır. C2 "Ë̆itim sadece bilginin sunulduğu bir sistem değildir. Biz sinıflarda öğrencilerimizin duygularmı da işe katarız. Bunu 1 saatlik derslerde uzaktan eğitimde yapmak oldukça güç. Bu durumda öğrencilerimize duyuşsal desteğ in de sağlanacağı bir alan yaratılmalı. Öğretmenler ve öğrencilerin bu anlamda sürekli etkileşim ve iletişim içinde olması çok önemli. Öğrenciler kendilerini değerli hissettikleri sürece daha verimli olacaklardir." seklinde kendisini ifade etmiştir. Bu kategoride bir katılımcı bir pilot uygulama önerisinde bulunmuştur. S13 "Bu görüşümü Millî Eğitim Müdürlüğüne de ilettim. Elazığ ilinde örneğin bizim okulumuz pilot okul seçilmeli ve İngilizce tüm dersler İletişim Lisesinin stüdyolarnnda kayıt altına alnmah. Öğretmenlerden gönüllü olanlar tüm yılın derslerinin videoların çekip sisteme yüklemeli. Öğrenciler istedikleri anda hangi ünitenin konusunu izlemek istiyorlarsa izlemeliler. Bu canl ders olmayacak anlamina gelmiyor. Bu videolarda dersler ayrntih bir şekilde anlatılmal ve yine her öğretmen kendisine düşen zamanda öğrencileriyle etkinlikler yaparak konuyu pekiştirmeli. Bu sistemin işe yarayacağın düşünüyorum.” diyerek önerisini grupla paylaşmıştır.

Öğrenciler için yapılan öneriler üç başlık altında toplanmıştır. İlk kod bireysel öğrenmeyi öğrenmedir $(F=4)$. Öğrencilerin bu kademede öğretmene çok fazla bağımlı olduğunu dile getiren katılımcılar bu süreçte bireysel öğrenebilen öğrencilerin daha başarılı olduğunu vurgulamış ve öğrencilerin bu anlamda desteklenmesi gerektiğini belirtmişlerdir. Bu doğrultuda yorum yapan E2 "Öğrencilerin ellerinde bilgisayarlar ve internetleri varsa orada bir dünya bilgiye ulaşma şansları da var demektir. Biz öğretmenler olarak onları yönlendirmeli ve hangi şekilde hangi yollarla daha iyi öğrenebileceklerini onlara göstermeliyiz. Yabancı dille ilgili sayısız görsel ve videolu anlatım içeren site var. Bizler gerekli incelemeleri yaptıktan sonra öğrencileri bu faydah siteleri kullanmaya teşvik etmeli bu şekilde onlarda istediğimiz alt yapının oluşumunu sağlamalıyz. Teknolojiyi düzgün kullanabilen öğrencilerin bu süreçte bireysel öğrenmelerine de katkı sağlayabileceğini düşünüyorum.” demiştir. Öğrencilerin teknolojiyi öğrenmek için kullanmaları öğretmenler tarafından yapılan önerilerdendir $(\mathrm{F}=3)$. C2 "Şimdiye kadar öğrencilerimiz bilgisayarların ve cep telefonlarm çoğunlukla oyun oynamak için kullanıyorlardı. Bu süreç onlara bu teknolojilerden eğitim için faydalanmaları gerektiğini gösterdi. Öğretmenlerin de desteğiyle öğrenciler yabancı dil öğreten web sitelerine ve cep telefonu uygulamalarma yönlendirilmelidir. Bu süreçte bu teknolojilerden faydalanmak gerekmektedir. Aslında bizler öğretmen olarak bu teknolojileri imkânımız çerçevesinde derslerimize dâhil etmekteydik. Şimdi görev öğrencilerin. İnteraktif yabancı dil öğrenebilecekleri çok sayıda uygulama ve internet sitesi var. Öğretmenler bu uygulamalar bir süzgeçten geçirip öğrencilerine tanitursa öğrenciler bu olanaklardan yararlanacaklardır.” diyerek öğrencilerin teknolojik olanaklardan mümkün olduğunca yararlanmaları gerektiğini belirtmiştir. Uzaktan eğitim sürecinde öğrencilerin motivasyon desteğine ihtiyaç duyduğunu belirten katılımcllardan ( $\mathrm{F}=3$ ) V5 "Ben geçtiğimiz süreçte öğrencilerime bu anlamda destek olamadım. Çünkü daha önce yaşamadiğımı bir durumdu ve bizler bile desteğe ihtiyaç duyduk. Ne öğretmenler ne de veliler bu

\footnotetext{
Adres Address

İstanbul Medeniyet Üniversitesi, Eğitim Bilimleri Fakültesi, Türkçe İstanbul Medeniyet University, Faculty of Education Sciences, ve Sosyal Bilimler Eğitimi Bölümü, Türkçe Eğitimi ABD Cevizli Turkish and Social Scinces Education, Turkish Language Teaching Kampüsü, Kartal-İstanbul/TÜRKIYE $\quad$ Education, Cevizli Campus, Kartal-İstanbul /TURKEY e-posta: editor@rumelide.com 1 e-mail: editor@rumelide.com
} 
anlamda öğrenim sürecinde öğrencileri motive edemedik. Yeni dönem uzaktan eğitimle devam ederse öğrencilere bu desteği sağlayacağımı düşünüyorum. Tüm öğretmenlerin de bu şekilde destek sağlaması gerektiğini düşünüyorum. Öğrencilere koçluk yapmamı gerekebilir.” yorumunu yapmıştır.

Veliler için önerilerde bulunan katılımcıların üzerinde en çok yorum yaptıkları mevzu $(\mathrm{F}=5)$ velilerin öğretmelerle sürekli iletişim içinde bulunmaları gerekliliğidir. C2 "Veliler bu süreçte öğretmenlerle gerek Whatsapp grupları gerekse bireysel yollarla iletişim içerisinde bulunmal ve öğrencilere nasıl yardımcr olabilecekleri konusunda öğretmenlerle iş birliği yapmahlar.” diyerek bu konudaki görüşünü belirtmiştir. Öğretmenlerin yanı sıra velilerin de uzaktan eğitimin nasıl olması gerektiğini anlamaları açısından eğitimlere ve seminerlere ihtiyaç duyduğunu düşünen katılımcılar $(\mathrm{F}=3)$ da bulunmaktadır. D7 “Öğrenciler, öğretmenler ve veliler eğitimin üç temel ayağıdır. Bizler öğretmen olarak nasıl ki yeni uzaktan eğitim sistemiyle ilgili desteğe ve eğitime ihtiyaç duyuyorsak veliler de bu konuda bilgilendirilmelidir.” yorumunu yapmıştır. Velilerin öğrencilere uygun çalışma ve öğrenme ortamı yaratılması gerektiğini vurgulayan V5 "Sonuç olarak unutulmamalıdır ki çocuklarımız uzaktan da olsa bir eğitim sürecindeler ve okul gibi olmasa da onlara rahat öğrenebilecekleri uygun ev ortamı ve çalışma alamı yaratılmalıdır. Zira televizyon izlenen odada canlı derse katılan öğrenciler verimli olmamakta."

Tüm katılımcıların hemfikir olduğu bir durum olan öğretmenlerin ve öğrencilerin bir kısmında süreç boyunca var olan teknolojik donanım eksikliği ve sınırlı internet kotasından kaynaklı erişim problemidir. Bu durumda C2 "Ben köyde olduğumdan ve internet erişimim kısıth olduğu için ders yapamadım. Öğrencilerimin de \% 3o'unun bu tip problemleri olduğunu biliyorum. Bakanlı̆̆mız tarafindan bu acil durum sürecine özel, tüm eğitim gören ve veren camiaya sinursız internet ve ihtiyaç duyanlara teknolojik donanım desteği verilmesi çok iyi olacaktır.” yorumunu yapmıştır.

\section{Sonuç, tartışma ve öneriler}

21. yüzyllda dünya çapında bir salgınla mücadele sürecinde eğitimciler şimdiye kadar vermedikleri kadar zorlu bir sınav vermektedirler. Normal şartlar altında bile daha önce uzaktan eğitim deneyimi olmayan eğitimcilerin bu süreci deneyimlemeleri birtakım sıkıntılara neden olabilirken (Conrad, 2004; Kayaduman \& Demirel, 2019), Covid-19 pandemi sürecinde deöğretmenler için bu sürece ayak uydurmak belirli bazı sıkıntılara neden olmuştur. Ancak teknoloji ve bilginin anlık hızlı değişimine ayak uydurmak noktasında öğretmenlere büyük görevler düşmektedir. Yabancı dil öğretimi de ülkelerin gelişimi noktasında devam etmesi gereken eğitimlerin başında gelmektedir. Bu noktadan yola çıkarak yaşanılan problemlere gerçekçi çözüm önerileri ortaya koyabilmek adına tasarlanan mevcut araştırmanın Covid-19 pandemi döneminde ortaokul düzeyinde görev yapan İngilizce öğretmenlerinin sürece dair görüş ve önerilerini ortaya koymuştur.

Araştırmanın ilk sonucu katılımcıların hepsinin bu süreçte EBA üzerinden doküman ve ödevlendirme yaparak süreci devam ettirmeye çalışmasıdır. Çevrim içi dersleri ise büyük çoğunlukla yapmaya çalışıp özellikle 8. sınıfları sınav dönemlerinde mağdur etmemek için mobil teknolojilerden faydalanmışlardır. Sınav ve ödev paylaşımlarını yabancı dil öğretiminde sıklıkla kullanılan (Alsaleem, 2014; Manan, 2017; Jasrial, 2018; Balcı \& Tezel, 2018) Whatsapp uygulamasından yararlanarak yürütmüşlerdir.

Adres 
Araştırmanın ikinci sonucu, süreçte yabancı dil öğretmenlerinin birçok problemle karşlaş̧tıklarıdır. $\mathrm{Bu}$ problemler sırasıyla, öğrenci; teknoloji; öğretmen ve veli kaynaklı problemlerdir. Öğrencilerde muhtemel olarak yaşanılan zorlu zamanlardan kaynaklı motivasyon düşüklüğü, çalışmaya karşı isteksizlik ve bunların dışında kendi kendilerine öğrenmeyi bilmemekten kaynaklı problemler dile getirilmiştir. Normal şartlar altında bile motivasyonun yabancı dil öğrenmeyi yakından etkilediği bilinmektedir (Al-Hazemi, 2000; Al Otaibi, 2004). Öğrencilerin bireysel olarak öğrenmeyi bilmemeleri de geçmişten beri süregelen öğretmen ve ders kitabı odaklı öğretim şeklinden kaynaklanmaktadır (Williams, 2017). Teknolojik donanım ve internet yetersizliği de araştırma kapsamında oldukça sık dile getirilen bir sorundur. Hem öğretmen hem de öğrenci bağlamında ele alınan bu sorun, sistemi büyük ölçüde etkilemektedir. Geleneksel yüz-yüze eğitimde dahi öğrenciler arasındaki toplumsal ve ekonomik eşitsizlik eğitimi etkilemekteyken; uzaktan eğitim sisteminde aradaki makas açılmakta ve bu bahsi geçen teknolojik yetersizlikler eğitimi aksatmaktadır. Teknik aksaklıkların uzaktan eğitimi etkilediği bazı çalışmaların sonuçlarında da mevcuttur (Jolliffe, 2001). Öğretmenler süreci değerlendirirken uzaktan eğitim sistemini daha önce kullanmadıklarını ve bu eğitimi tam olarak almadıklarını belirten öğretmenler bir takım şahsi problemler nedeniyle de sistem sıkıntıları yaşadıklarını dile getirmişlerdir. Uzaktan eğitim sistemine yabancılık çekmenin endişeye neden olduğu yapılan çalışmaların sonuçları arasındadır (Ushida, 2005). Özellikle yaşı daha ileri olan öğretmenlerin teknolojik anlamda bilgi eksikliklerinin oluşu da bu sistem için önemli bir problemdir. Eğitimin üçüncü ayağı olan veli unsuru da problemler çerçevesinde değinilen bir mevzu olmuştur. Veli desteği alan öğrencilerin eğitim süreçlerinde daha başarılı oldukları bilinmektedir (Gardner, 1985; Roth, 2008). Velilerin uzaktan eğitim sistemi ile ilgili yeterli bilgiye sahip olmadıkları için gerekli desteği gösterememeleri ve de mevcut sıkıntılı durumda ekonomik problemler yaşayıp bunu öğrencilere yansıtmaları bahsedilen sıkıntılardan olmuştur.

Araştırmaya katılan öğretmenlerin her bir problem çerçevesinde yapmış oldukları öneriler araştırmanın son sonucunu oluşturmaktadır. Öğretmenlerin eğitim sürecinde büyük öneme sahip oluşu, çalışmanın başından beri vurgulanmaktadır. Katılımcıların en fazla öneride bulunduğu faktör de öğretmen faktörü olmuştur. Öğretmenlerin uzaktan eğitimle ilgili yeterliklerinin artması için seminerler düzenlenmesi gerekliliği yapılan ilk öneridir. Karaca vd. (2011) de uzaktan eğitimin daha verimli olabilmesi için öğretmenlere teknoloji korkularının üstesinden gelmek üzere eğitimler verilmesi gerektiği önerisinde bulunmuşlardır. İkinci olarak yüz yüze sınıf ortamlarında uygulanan yöntem ve tekniklerin uzaktan eğitime göre yeniden şekillenmesi gerektiği belirtilmiştir. Özellikle iletişimsel yöntemlerin süreçte mutlaka faydalanılması gerektiğini belirten öğretmenler bunun için ders saatlerinin artırılmasının üzerinde durmuştur. Yabancı dil öğretiminde iletişimsel yaklaşımın gerekliliği alanda çalışılan konuların başında gelmektedir (Littlewood, 1992; Richards \& Rodgers, 2001; Zhou \& Griffiths, 2011). Uzatan eğitim sürecine ölçme ve değerlendirme basamağının mutlaka dâhil edilmesi gerektiği; öğrencilerin yaşadıkları bu zorlu süreçte bilişsel yönden olduğu kadar duyuşsal yönden de desteklenmeleri gerektiği belirtilmiştir. Tok (2010) yabancı dil öğretiminde amacın öğrencilerde bilişsel alanda olduğu kadar duyuşsal alanda da davranış değişikliği meydana getirmek olduğunu belirtmektedir. Öğrencilerin duygularına hitap ederek onları motive etmek ve de derse karşı tutumlarını geliştirmek uzaktan eğitim sürecine katkı sağlayacaktır. Zira Bozkurt ve Sharma da (2020) öğrencilerin bu zorlu kriz sürecini atlattıktan sonra ne öğrendiklerini değil de bu süreçte nasıl desteklendiklerini ve nasıl değer verildiklerini hatırlayacaklarını belirtmişlerdir. Bu kategoride yapılan son öneri de yeni bazı uygulamaların pilot uygulamalar şeklinde denenip eğitim sistemine dâhil edilmesidir. Öğrenci merkezli bir öğrenme şekli olan uzaktan eğitime adapte olabilmek için öğrencilerin bireysel öğrenmeyi bilmeleri gerektiği; bilmiyorlarsa bu alanda destek almaları gerektiği üzerine en çok konuşulan öneri olmuştur. 21. yüzyll gibi bilgi ve teknoloji çağında

\footnotetext{
Adres $\mid$ Address

İstanbul Medeniyet Üniversitesi, Eğitim Bilimleri Fakültesi, Türkçe İstanbul Medeniyet University, Faculty of Education Sciences, ve Sosyal Bilimler Eğitimi Bölümü, Türkce Eğitimi ABD Cevizli Turkish and Social Scinces Education, Turkish Language Teaching Kampüsü, Kartal-İstanbul/TÜRKIYE $\quad$ Education, Cevizli Campus, Kartal-İstanbul /TURKEY e-posta: editor@rumelide.com 1 e-mail: editor@rumelide.com
} 
öğrencilerin teknolojiyi öğrenmek için kullanmaları ve de onları bu süreçte motive ederek desteklemek gerektiği vurgulanmıştır. Öğrencilerin uzaktan eğitim süreci boyunca motivasyonlarını kaybetmeye meyilli olabilecekleri ve öğrenciler için süreçte devamlı olarak motivasyon unsurlarının uygulanması gerekmektedir (Karaca, vd., 2011). Veliler bazında yapılan önerilerin ilk başında onlarla sıkı iletişim kurmanın sistemi güçlendireceği ve uygun iletişim yollarının bulunması gerektiğidir. Öğretmenlere teknik bilgi desteği bazında uygulanacak seminerlerin velilere de bilgilendirme amaçlı uygulanması gerektiği belirtilmiştir. Velilerin öğrencilere uygun çalışma ortamı yaratmaları gerektiği yapılan öneriler arasındayken; teknolojik anlamda eşitsizliği önlemek noktasında hem öğrencilere hem de öğretmenlere teknik destek sağlanması gerektiği de tüm katılımcıların hemfikir oldukları bir noktadır.

Eğitim ortamlarında dijitalleşme Covid 19 pandemisine kadar bu denli önemli olmamıştı. Bu dönemde yapılan çalışmalar da dijital eğitim alanında esasında oldukça yavaş hareket edildiğini gösterdi. Başka bir değişle virüs insanlara dijitalleşmeden başka çare olmadığını göstererek dijital alfabeyi ezberletti (Coeckelbergh, 2020). Bundan sonraki süreçte eğitim ortamlarında öğrenenlerin geleneksel öğretim uygulamaları yerine dijital içerikli uygulamaları daha fazla kullanacakları ve bu yeni normal sürecinde kendi öğrenmelerini yönetmeleri gerektiği ön görülmektedir (Bozkurt, 2020). Zira Eren’in (2020) de belirttiği gibi pandemi döneminde yaşanılanların değerlendirilip yeni politikalar üretilmesi gerekmektedir. Bu yenileşmeden payını alacak alanlardan birisi de yabancı dil öğretimi olacaktır. Yabancı dil öğretimi ortamlarında erek dile maruz kalma ve yüz yüze etkileşim oldukça önemli iki kavramdır. Ancak pandemi döneminde başvurulan uzaktan eğitim sisteminin avantajları da azımsanmayacak boyuttadır. O halde bu durumu olumsuz bir durum olmaktan çıarıp firsata dönüştürmek gerekmektedir. Bozkurt'un (2020: 118) da belirttiği gibi 'Bu süreçle beraber uzun vadede bu tecrübelerin genel eğitim paradigmasına yansımalarının olması kaçınılmazdır. Her kriz devamında bazı firsatlar doğurur'. Bu noktada yabancı dil öğretimi bağlamında da paydaşlar süreci iyi yönetip yeni eğitim paradigmasına başarılı bir şekilde yön vermelidir.

\section{Kaynakça}

Acat, B \& Demiral, S. (2002). Türkiye'de yabancı dil öğreniminde motivasyon kaynakları ve sorunları. Kuram ve Uygulamada Ĕ̆itim Yönetimi Dergisi, 8(31), 314-326.

Al-Hazemi, H. (2000). Lexical Attrition of Some Arabic Speakers of English as a Foreign Language: a Study of Word Loss. Internet TESL $\mathrm{J}$ [Serial online] Retrieved from: http://iteslj.org/Articles/Al-Hazemi-Attrition/

Allen, E. \& Seaman, J. (2010). Class differences: Online education in the United States. Babson Survey Research Group Report. The Sloan Consortium. Retrieved from: https://files.eric.ed.gov/fulltext/ED529952.pdf.

Al-Mohammadi, A. \& Derbel, E. (2014). The effects of embedding information technology within ELT on EFL learners"e motivation and internet." International of Applied Linguistics \& English Literature 3(1), 181-186.

Al-Otaibi, G. (2004). Language Learning Strategy Use among Saudi EFL Students and Its Relationship to Language Proficiency Lever, Gender, and Motivation [Doctoral Dissertation]. Proquest Dissertations Publishing. (3129188).

Alrubaie, S.A., \& Alrubaie, M.A., \& Hassoon, I.M. (2020). The Role of Activating Electronic Training in Increasing Efficiency of Training Process. Journal of Southwest Jiaotong University, 55 (1), 111.

Alsaleem, B. I. A. (2014). The effect of "WhatsApp" electronic dialogue journaling on improving writing vocabulary word choice and voice of EFL undergraduate Saudi Students. Harvard: 21st Century Academic Forum Conference Proceedings.

\footnotetext{
Adres $\mid$ Address

İstanbul Medeniyet Üniversitesi, Eğitim Bilimleri Fakültesi, Türkçe İstanbul Medeniyet University, Faculty of Education Sciences, ve Sosyal Bilimler Eğitimi Bölümü, Türkçe Eğitimi ABD Cevizli $\quad$ Turkish and Social Scinces Education, Turkish Language Teaching Kampüsü, Kartal-İstanbul/TÜRKIYE $\quad$ Education, Cevizli Campus, Kartal-İstanbul /TURKEY e-posta: editor@rumelide.com $1 \begin{aligned} & \text { e-mail: editor@rumelide.com } \\ & \text { e-com }\end{aligned}$
} 
Atreya, A. \& Acharya, J. (2020). Distant virtual medical education during Covid-19: Half a loaf of bread. The Clinical Teacher, 17, 418-419.

Bahrani, T., \& Tam, S. S. (2011). Technology and language learning: Exposure to TV and radio news and speaking proficiency. Kritika Kultura, 17, 144-160.

Bal, S. M. (2006). Teachers' Perceptions of Communicative Language Teaching (Clt) In Turkish EFL Setting Theory Vs. Practices. (Yüksek Lisans Tezi) Çukurova Üniversitesi Kütüphanesi. (6326).

Balci, A., \& Tezel Şahin, F. (2016). Sosyal medyanın aile katılımında kullanılabilirliği üzerine bir inceleme. Kastamonu Üniversitesi Kastamonu Ĕ̈itim Dergisi, 24(5), 2309-2322.

Baxter, J., \& Eyles, J. (1997). Evaluating qualitative research in social geography: Establishing 'rigour' in interview analysis. Transactions of the Institute of British Geographers, 22(4), 505-525.

Becker, H. J. (2000). Findings from the teaching, learning, and computing survey: Is Larry Cuban right? Education Policy Analysis Archives, 8(51).

Berg, B. L. (2001). Qualitative Research Methods for Social Sciences. Boston: Allyn \& Bacon.

Bozkurt, A. (2020). Koronavirüs (Covid-19) pandemi süreci ve pandemi sonrası dünyada eğitime yönelik değerlendirmeler: Yeni normal ve yeni eğitim paradigması. Açıköğretim Uygulamaları ve Araştırmaları Dergisi, 6(3), 112-142.

Bozkurt, A., \& Sharma, R. C. (2020). Emergency remote teaching in a time of global crisis due to CoronaVirus pandemic. Asian Journal of Distance Education, 15(1), i-vi.

British Council \& Tepav (2013). Türkiye’deki Devlet Okullarında İngilizce Dilinin Öğretimine İlişkin Ulusal İhtiyaç Analizi. Ankara: Yorum Yayın.

Burrows, D., \& Kendall, S. (1997). Focus groups: What are they and how can they be used in nursing and health care research? Social Sciences in Health 3, 244-253.

Cavanagh, S. (1997). Content Analysis: Concepts, Methods and Applications. Nurse Researcher, 4, 516.

Coeckelbergh, M. (2020). The postdigital in pandemic times: A comment on the Covid-19 crisis and its political epistemologies. Postdigital Science and Education,2, 547-550.

Conrad, D. (2004). University instructors' reflections on their first online teaching experiences. Journal of Asynchronous Learning Network, 8(2), 31-44.

Daniel, S. J. (2020). Education and the COVID-19 pandemic. Prospects, 1-6, Advance online publication. https://doi.org/10.1007/s11125-020-09464-3

Fansuary, A. H., \& Januarty, R., \& Rahman, A.W. \& Syawal, (2020). Digital Content for Millennial Generations: Teaching the English Foreign Language Learner on Covid-19 Pandemic. Journal of Southwest Jiaotong University, 55(3), 1-12.

Far, R. M., \& Trukowski, E., \& Holz, E. (1996). Public Opinion, Group Discussion and Theory of Social Representations. (Research Papers in Psychology No: 9602). London School of Economics.

Graddol, D. (1997). The future of English? A guide to forecasting the popularity of the English language in the 21st century (Vol. 29). The British Council. Retrieved from https://doanbangoc.files.wordpress.com/2012/07/the-future-of-english.pdf

Guba, E. G. (1981). Criteria for assessing the trustworthiness of naturalistic inquiries. Educational Communication and Technology Journal, 29, 75-91.

Iivari, N., Sharma, S., \& Ventä-Olkkonen, l. (2020). Digital transformation of everyday life - How COVID-19 pandemic transformed the basic education of the young generation and why information management research should care? International Journal of Information Management, 55, 1-6.

Jasrial, D. (2018). Utilizing WhatsApp application for teaching English language: Why and how?. International Seminar and Annual Meeting BKS, 1(1), 151-157. 
Jolliffe, A., Ritter, J., \& Stevens, D. (2001). The online learning handbook: Developing and using webbased learning. UK: Kogan Page Limited.

Karaca, O., Topal, M.\& Aldir, Z. (2011). Uzaktan eğitim sorunları. Uluslararası Bilim ve Teknoloji Konferansında sunulan ,bildiri, 7-9 Aralı, İstanbul. Erişim adresi: https://www.researchgate.net/profile/Ozan_Karaca/publication/273057693_Uzaktan_Egitim _Sorunlari/links/54f5b0420cf2f28c1366aodc/Uzaktan-Egitim-Sorunlari.pdf

Kayaduman, H., \& Demirel, T. (2020). Investigating the Concerns of First-Time Distance Education Instructors. International Review of Research in Open and Distributed Learning, 20 (5), 85-103.

König, W. (1989). Türkiye'deki yabancı dil öğretim sorunları, dışardan bir bakış. Hacettepe Üniversitesi Eğitim Fakültesi Dergisi, 4, 167-172.

Kunnan, A. J. (2005). Language assessment from a wider context. In E. Hinkel (Ed.), Handbook of research in second language teaching and learning. Mahwah, NJ: Lawrence Erlbaum.

Lincoln, Y., \& Guba, E. G. (1985). Naturalistic inquiry. Thousand Oaks, Calif: Sage.

Littlewood, W. (1992). Teaching oral communication: A methodological framework. Oxford: Blackwell.

Liu, M., Moore, Z., Graham, L., \& Lee, S. (2002). A Look at the research on computer-based technology use in second language learning. Journal of Research on Technology in Education, 34(3), 250-273.

Manan, N. A. (2017). Whatsapp mobile tool in second language learning. Indonesian EFL Journal, $3(1), 87-92$.

Merriam, S. B. (1998). Qualitative Research and Case Applications in Education. San Francisco: Jossey-Bass.

Millî Eğitim Bakanlığı. (2008). Türkiye’nin Eğitim İstatistikleri . http://www.meb.gov.tr.html. adlı adresten alınmıştır.

Osterloh, K. H. (1982). Die Rolle der sozialen Vorerfahrung im Fremdsprachenunterricht in der Türkei (Türkiye'de yabancı dil öğretiminde toplumsal öndeyin rolü). Birkenfeld. Helmut (Ed): Qastarbciterkinder aus der TürkeI. Zwishei Eingliederung und Rückkehr. -München; s. 44 - 54 ve $165-166$.

Özsevik, Z. (2010). The Use of Communicative Language Teaching (CLT): Turkish EFL Teachers' Perceived Difficulties in Implementing CLT in Turkey (Master Thesis). Available at https://www.ideals.illinois.edu/bitstream/handle/2142/16211/Ozsevik_Zekariya.pdf?seq uence $=2$.

Öztürk Karataş, T., \& Tuncer, H. (2020). Sustaining Language Skills Development of Pre-Service EFL Teachers despite the COVID-19 Interruption: A Case of Emergency Distance Education. Sustainability, 12 (19), 8188.

Paker, T. (2012). Türkiye'de neden yabancı dil (İngilizce) öğretemiyoruz ve neden öğrencilerimiz iletişim kurabilecek düzeyde ingilizce öğrenemiyor? Pamukkale Üniversitesi Eğitim Fakültesi Dergisi, 32, 89-94.

Parvin, R. H., \& Salam, S. F. (2015). The effectiveness of using technology in English language classrooms in government primary schools in Bangladesh. FIRE: Forum for International Research in Education, 2(1), 47-59.

Pourhosein Gilakjani, A. (2013). Factors contributing to teachers' use of computer technology in the classroom. Universal Journal of Educational Research, 1(3), 262-267.

Richards, J. C., Rodgers, T. S. (2001). Approaches and Methods in Language Teaching, Second Edition, Cambridge Language Teaching Library, USA: Cambridge University Press.

Rodinadze, S., \& Zarbazoia, K. (2012). The advantages of information technology in teaching English language. Frontiers of Language and Teaching, 3, 271-275.

\footnotetext{
Adres $\mid$ Address

İstanbul Medeniyet Üniversitesi, Eğitim Bilimleri Fakültesi, Türkçe İstanbul Medeniyet University, Faculty of Education Sciences, ve Sosyal Bilimler Eğitimi Bölümü, Türkçe Eğitimi ABD Cevizli $\quad$ Turkish and Social Scinces Education, Turkish Language Teaching Kampüsü, Kartal-İstanbul/TÜRKIYE $\quad$ Education, Cevizli Campus, Kartal-İstanbul /TURKEY e-posta: editor@rumelide.com 1 e-mail: editor@rumelide.com
} 
Roth, B. (2008). The Importance of Parental Encouragement and Support. Retrieved from http://ezinearticles.com/?The-Importance-of-Parental-EncouragementandSupport\&id $=1622042$

Russell, V., \& Curtis, W. (2013). Comparing a large- and small-scale online language course: An examination of teacher and learner perceptions. Internet and Higher Education, 16, 1-13.

Santana De Oliveira, M.M., \& Torres Penedo, A.S., \& Pereira, V. (2018). Distance education: Advantages and disadvantages of the point of view of education and society. Dialogia, 29, 139152.

Sato, K., \& Kleinsasser, R. (1999). Communicative language teaching: practical understandings. The Modern Language Journal. 83 (iv), 94-517.

Shenton, A. K. (2004). Strategies for ensuring trustworthiness in qualitative research projects. Education for Information, 22, 63-75.

Silverman, D. (2010). Doing qualitative research: A practical handbook (3rd edition). London: Sage.

Smedley, J.K. (2010). Modelling the impact of knowledge management using technology. Insight 23, 233-250.

Ta'amneh, M. A. A. (2017). The effect of using WhatsApp Messenger in learning English language among university students. International Research in Education, 5 (1), 143-151.

Thomas, L., \& Macmillan, J.,\& Mccoll, E.,\& Hale, C., \& Bond, S. (1995). Comparison of focus group and individual interview methodology in examining patient satisfaction with nursing care. Social Sciences in Health 1, 206-219.

Tok, H. (2010). Üniversite öğrencilerinin İngilizce dersine ilişkin duyuşsal tutumlarının bazı değişkenlere göre incelenmesi. Millî Ĕ̆itim Dergisi, 185, 90-106.

Tümen Akylldı, S. (2020). College students' views on the pandemic distance education: A focus group discussion. International Journal of Technology in Education and Science (IJTES), 4(4), 322334 .

UNESCO. (2020). COVID-19 educational disruption and response. Retrieved from https://en.unesco.org/ covid19/education response

Ushida, E. (2005). The role of students' attitudes and motivation in second language learning in online language courses. CALICO Journal, 23(1), 4978.

Warschauer, M. (2000). The death of cyberspace and the rebirth of CALL. English Teachers' Journal, $53,61-67$.

Wilkinson, S. (2015). Focus groups, in: J. A. Smith (Ed), Qualitative Psychology: A Practical Guide to Research Methods. London: Sage.

Williams, C. H. (2017). Teachers in East Asia: A teacher's guide to Chinese, Japanese, and Korean learners. Singapore: Springer.

World Health Organization-WHO (2020). Coronavirus disease (COVID-19) advice for the public. Coronavirus disease 2019. Retrieved from https :// www.who.int/emerg encie s/disea ses/novel -coron aviru s-2019/advic e-for-public.

Yi, Y., \& Jang, J. (2020). Envisioning possibilities amid the COVID-19 pandemic: Implications from English language teaching in South Korea. Current issues in TESOL: TESOL and the Covid-19 pandemic, 11(3).

Zhou, C., \& Griffiths, C. (2011). Intercultural communicative competence. English Language and Literature Studies, 1, 113-122.

Zhu, C. (2010). Teacher roles and adoption of educational technology in the Chinese context. Journal for Educational Research Online, 2(2), 72-86. 